\title{
Conjugal Dissolution and Gender (In)equalities: A Study of Divorce Processes in Portugal
}

\author{
Manuel Carlos Silva ${ }^{a}$, Ana Reis Jorge ${ }^{b}$
}

\begin{abstract}
Like other democratic societies, Portugal has known an important reduction of gender inequalities, mainly by the action of women's social movements and some political forces. However, recent (inter)national studies confirm the social borders and inequalities persistence in many contexts (work, values and symbolic regulations, institutional frames, and daily interactions). In this paper, the authors will focus their analysis on the conjugal dissolution processes and unequal distribution of power between men and women. Regarding these matters, there is an extended debate, where they propose an articulation between the concepts of gender and class. The authors assume as fruitful an articulation of the Marxist model with the feminist one and, indirectly, a critical and synthetic crossing between (neo)Marxism and Weberianism, being this one also articulated with symbolic interactionism. Based on official statistics, in the analysis of some interviews about the motivations for/in divorce, and in the empirical evidence from the divorce judicial processes, the authors present some preliminary results of a collective project held on some regions of Portugal named: "Gender inequalities in work and private life: from the norms to social practices". The central hypothesis of this project is that the forms of gender inequality and domination are tributaries of macro-economic and institutional mechanisms but they are also playing at the micro level (family, business, public and private institutions), involving both variables, namely, in a crossing of Weberian-Marxist perspectives, the presence/absence of certain level of empowerment by social actors. That means that women's position depends and/or differs in function of factors such as available resources and rewards, the place in the organizational and (re)productive sphere of the family, and the place in the interactions and in roles negotiation.
\end{abstract}

\section{Keywords}

Divorce, gender, class, inequalities, domestic power

Portugal has known, particularly after April 1974, a decrease in gender inequalities, namely on account of women social movements and certain political forces. Despite relative progress, in political and legal terms, several national studies attest, in defense of principles of equalitarian treatment in men-women relationships, the permanence of important asymmetries in various dimensions of social life such as sexual division of work, control of domestic space, honor-shame codes (Silva 1993; 1998; Wall 2005); sexual segmentation of work markets, the matrix of opportunities and wages (Ferreira 1993); professional careers and participation/leadership of political activities (Viegas and Faria 1999); heritage and marriage systems

aUniversity of Minho, Portugal/National University of Brasilia, Brazil

bUniversity of Minho, Portugal

\section{Correspondent Author:}

Manuel Carlos Silva, Interdisciplinar Centre of Social Sciences (CICS.Nova), University of Minho, ICS, Campus Gualtar, 4710-057, Braga, Portugal 
(Torres 2001); daily circumstances and interactions, symbolic world views and institutional circumstances, even judicial power. In fact, although the law is conceptually based on ideas of impersonality and neutrality, various authors have shown the present unevenness between those and effective judicial action. Numerous feminist authors show that binary stereotypes about feminine-masculine are boldly accentuated in law and in justice administration (Smart in Abbott and Wallace 1991). If, such thing occurs in the most disparate sectors to the disadvantage of women, then it is also damaging for them in most of the separation/divorce processes and forces women to seek aid through defensive strategies quite often only detectable in "hidden records" (Scott 1990). However, we should not exclude those cases, even if they are a minority, as we will see, when men can feel injured by their rights.

After a brief theoretical framing, the authors will display some historical and statistical data about divorce, and finally, they will analyze 331 divorce processes initiated by litigation in 10 Portuguese courts: Braga, Guimarães, Santo Tirso, Barcelos, Famalicão, Póvoa de Varzim, Vila do Conde, Porto, Torres Novas, and Leiria. The authors lay emphasis, through a gender point of view, on the analysis of inherent motivations to the divorce and in the characteristics of the cases.

\section{INEQUALITY AND GENDER CONFLICT: BRIEF THEORETICAL FRAMING}

In a brief synthetic and critical revisitation of some theoretical paradigms about the gender inequalities [structural-functional, (neo)Marxist and (neo)Weberian], the authors intend, with this text, to articulate Marxist, Weberian, and feminist conceptions, crossing the notion of gender with notion of class. Their work ${ }^{1}$ is based on the premise that besides macro-economical interest and institutional domination mechanisms, feminine work strength control and ensuing segregation phenomena and wage discrimination are reproduced on socio-structural, organizational-institutional, and interactive levels.

Within a micro and meso scale, women's power changes as a result of several factors such as available resources, participation in productive processes, hierarchical ordinance of sexual roles in sexual division of work, well present in conjugal and post-conjugal relationships (divorce and child custody); the position taken in the organization of each corporation or institution; the position taken in reproductive spheres of family unity; and, eventually, the compliant dissolution and restoring of roles in interactions and negotiations.

Before the authors express their point of view, let them do a brief revisitation of the current theoretical approach about gender inequalities in contemporary societies in order to debate its difficulties and lacks afterwards. The structural-functional model, which has been described as "sociology of sexual roles", and is regarded as intentional for some but not necessary for others, implies an antifeminist orientation and perhaps the first dramatic example of lack of involvement from conventional sociology in feminism ever since the 60’s (Ritzer 1996: 444). Parsons (1956) provided the best depiction of this conventional theory in the heart of sociology, not paying any attention to questions of gender, except for when he reproduces the dominant model of those who are said to be middle classes and presents them as role models to the remaining classes. According to Parsons (1956), the institution of family provides an indispensable contribution to social stability and internalization of social control. Differentiated functions per gender among the family - the "instrumental" by the man and the "expressive" by the woman-would be regarded also as biological and anatomical differences. According to this point of view, the "instrumental function" held by the man would make him the sole breadwinner at home, and the "expressive function" held by the woman, would guarantee the family's 
internal functioning, in order to look after their children, the husband, and other adult aggregates, both materially and emotionally. If men and women are similar, there will be competition between them, and along with it, the weakening of the family as vehicle of social stability.

From a different standpoint than the structural-functional vision, the interactionist symbolic perspective considers that gender inequalities shall be put into context, by revealing practice and interactions, modes of performance and cultural expression which is coded in language, in gestures, and in the capacity of negotiating masculine and feminine identities (cf. Goffman 1974).

On one hand, organizational or institutional-type explanations are based on unequal distribution of power, not only in family, as well as in work, educational and political circuits. On the other, this power-centered view is shared by several feminists (Roberts 1984) and is affiliated with the Weberian conceptualization of authority and power (Weber 1978), and with various later theorists who focused on this matter such as Segalen (1983), Bourdieu (1980), Silva (1993; 1998), and Machado (2005) who looked at the institution of family as one of the main stages for political and economical control of heritage and sexuality, where power and authority relationships trigger tensions and conflicts that sometimes disrupt unity and domestic integration.

The conflict between men and women, both outside and within the family itself, as well as situations of convergence of interests, of sympathetic share of emotions and affection; have displayed a fundamental role which mirrors the circumstances of gender inequality throughout the centuries. Already in the nineteenth century, Engels (1964) insisted that male strategies applied to the sexual division of work, intending to consolidate control over women, lead to the explanation of the origin of private property and the state. However, this ambivalence as approached by the traditional Marxist view, focused more on the explanation of class and paid less attention to the conflict of gender, neglecting the role of (para)statal institutions and the structure of power itself in the midst of the family. In addition, traditional Marxism did not pay enough attention to household work as the basis for gender domination and inclusively, in various examples, for class exploration.

In the seventies, radical feminism addressed the sharpest critique to traditional Marxist conception, by saying that women are more oppressed by patriarchal system than by the class system. Patriarchate is not only the first historical structure of dominance and submission, as it still remains today the most pervasive system of inequality, or in other words, the basic model of dominance (Walby 1997).

In the authors' point of view, reconstruction of Marxism, namely in this area, and the articulation between gender and class concepts are possible and can be fruitful for the analysis of gender relationships. Conflict, diversity, and heterogeneity are diluted in gender relationships, in the gender division of work, in discourses and in ideologies about motherhood, masculinity, and femininity and, as such, they shape the character of contemporary families. Institutions and programs about social protection, the fulfilling or not of citizenship principles and the availability of public services related to the welfare state affect gender relationships in various ways and, most certainly, the divorce and child custody processes after divorce.

\section{DIVORCE EVOLUTION IN PORTUGAL: LAW AND NUMBERS}

It is known that the promulgation of the first divorce law in Portugal goes back to the implantation of the I Republic, having meant an effort of laicization of divorce by the state, as well as the increment of rights and individual liberties. Its utterance was then several times considered as one of the most advanced in Europe for that time, namely because of the 
implementation, along with it, of the divorce by mutual consent, characterized by its egalitarian nature. However, when compared to other countries with similar legislation, the number of divorce cases in Portugal was not considered relevant after the promulgation of the law, and was limited in large scales to urban areas and the most educated sectors of the medium and high economic level population.

The legislation advances that came with the I Republic suffered a serious setback, having been re-replaced by the old and retrograde conceptions with the consolidation of the "Estado Novo" regime, and in particular with the signature of the "Concordata" between the state and the Catholic Church (Santa Sé) in 1940. This agreement, that focused on Catholic marriage, erased the separation between the church and the state and, consequently, implemented the legal indissolubility of Catholic marriage. After the year of 1946, when 1.181 divorces were filed, the sharp and graphically rectilinear diminution of divorce cases was particular revealing, specially taking in consideration that Catholic marriage is the predominant form of conjugal union in such period, while in 1970 there was a maximum peak of 509 cases. Regardless of this, the number of judicial separation cases of people and goods is still worth mentioning. If in 1959 there was a total of 373 cases, in 1974 the number raised to 878, with a particularly visible growth from 1970 on. Judging from these facts, we can observe the actual divorce intention, which however was not permitted by law. And this conclusion is strengthened when we look at the high number of separation of people and goods that was turned into divorce cases right after the promulgation of the Enactment of 1975.

If in several European countries, as well as the U.S.A., the 60s was marked by an astounding increase in the number of divorce, possibilities for that to happen in Portugal were even more limited by the Civil Code of 1966, in which divorce was by mutual consent in cases of civil marriage. In these cases, the only possible solutions were the litigious way or separation of people and goods, either by mutual consent, or with the possibility of conversion in divorce after three years, this one being exclusive to civil marriage.

In effect, it was not until the April Revolution of 1974, more precisely with the May 27, 1975 Enactment, that divorce was allowed once again, as well as for the mutual consent option, being that in 1977 one other Enactment triggered a variety of family rights, and some of them connected to gender equality. Like Torres (1996) pointed out, by the time of the I Republic:

Who defended this type of program belonged to a cult bourgeoisie, that proposed new legislation in the name of a new ethic. In 1974, the arguments are of a more pragmatic and immediate nature (...) The affected individuals themselves strived on implementing it (...) of putting a stigmatizing situation to an end, of expressing the wish of acting within the law and showing how difficult it was to live outside it. (Torres 1996: 39)

Between the years of 1975 and 1978, there is a striking increase on the number of divorce cases, partly explainable by the amount of people and goods separation cases that were regularized. From that date on, one can witness a regular growth until the year of 2002, year in which, in terms of total value, there was the highest increase and, proportionally, the biggest annual variation ever since 1997 until the year of 2007. In this year, 25.255 divorces $^{2}$ were filed, the second highest value of the actual decade, on which some fluctuation took place (by slight decrease in 2001, 2003, and 2005). Changes in the juridical field for the requirements to get the divorce process started, and in particular the tendency to end with bureaucratization certainly influenced those values.

In regards to the divorce modality (see Figure 1), it is noticeable that, if between 1975 and 1979, litigious divorces were in bigger number (48\%), followed by the ones with mutual consent (44\%), ending with the conversion of separation in divorce (8\%); after the decade of 1980 , divorce by mutual 
agreement clearly became the majority, reaching the $67.8 \%$ in that same decade, $77.3 \%$ in the 90 s, and $90.9 \%$ in 2002. Separation processes for divorce became scarce in the period subject to analysis. These numbers refer to processes that are closed, and it is certain that a considerable part of divorces that are initially litigious is later converted to mutual consent.

In Portugal, progressive growth in divorce leads to an approximation to European numerical values. During the decades of 80 and 90, in general terms, although Portugal had divorce rates leaning to be higher than the rest of Southern Europe countries-which is partly explained by the more advanced juridical setting in Portugal after the April 25 and the republican and secular state in comparison, with for instance, Spain and Italy ${ }^{3}$-it revealed much inferior numerical values than countries of Northern and Central Europe. However, in the year of 2002, the rate of divorceability (2.7\%o)-proportion between number of enacted divorce cases and resident population-left Portugal side to side with EU countries which possessed the highest signs $(2.4 \%$ in Sweden, 2.5\% in Finland, 2.7\% in Denmark, and 2.9\%o in Belgium). In Portugal, the last collected data from 2007 pointed towards a rate of $2.4 \%$, therefore keeping the tendency to occupy a high place in a European context.

For this surprising increase on the last decades, one cannot overlook the extensive social transformations that took place in the country, which developed into important juridical reforms, tendentially leading to the accomplishment of gender and family equality. In fact, for a short period of time, social constraints for divorce were weakened, owing to changes in the way of looking at marriage to the extent of practice and familiar conceptions, with the increasing raise of the importance of individual welfare and autonomy and liberty conducting private life.

Women's affirmation, specially in regards to paid work and professional aspirations contributed in large scale for such, and the economic dependence became each time less an obstacle to file for divorce. Next to a lesser economical dependency from the woman, and the eventual reciprocally related loss of male power in the midst of several families, one should point out the exponential growth of higher cultural and scientific resources acquisition by an increasing group of graduate women (graduate, masters, and $\mathrm{PhD}$ ), like it is shown by statistics.

In a context of urban growth in mid-sized and big Portuguese cities, the relative feminine liberation of social control in traditional rural settings, not only in the so mentioned middle classes, but also among female children of those working classes, led to the lack of restraints by this new generation of young people and freed them from village- and family-type social constraints. At last, the loss of the church and its local representatives' penalizing power, the influence that the media brought to the change of mentalities and habits, also weakened the social-moral pressure exerted over their habitants, particularly women, and in special the youngest, therefore tolerating, if not relativising, the dissolution of marriage.

However, such advances, as mentioned before, did not lead to the extinction of asymmetries, instead, the tendency for divorce and its experience varied from region to region, and in gender, class, and degree of education, which bring the importance of presence/absence of certain resources. Thus, dissolution of marriage occurs more frequently in urban areas, whereas the most affected regions were those of Lisbon and Vale do Tejo region, followed, even if proportionally, by the regions of the North of the country and Alentejo, which went from .8\%o in 1993 to $2.2 \%$ in 2002 . It is worth pointing out that, although it has assisted to a generalized decrease in Catholic marriage, it is in the northern region of this country where values are higher, and marriage rupture is higher in civil marriages. This modality is still the majority nowadays, even though its distance from the other is not as relevant. 


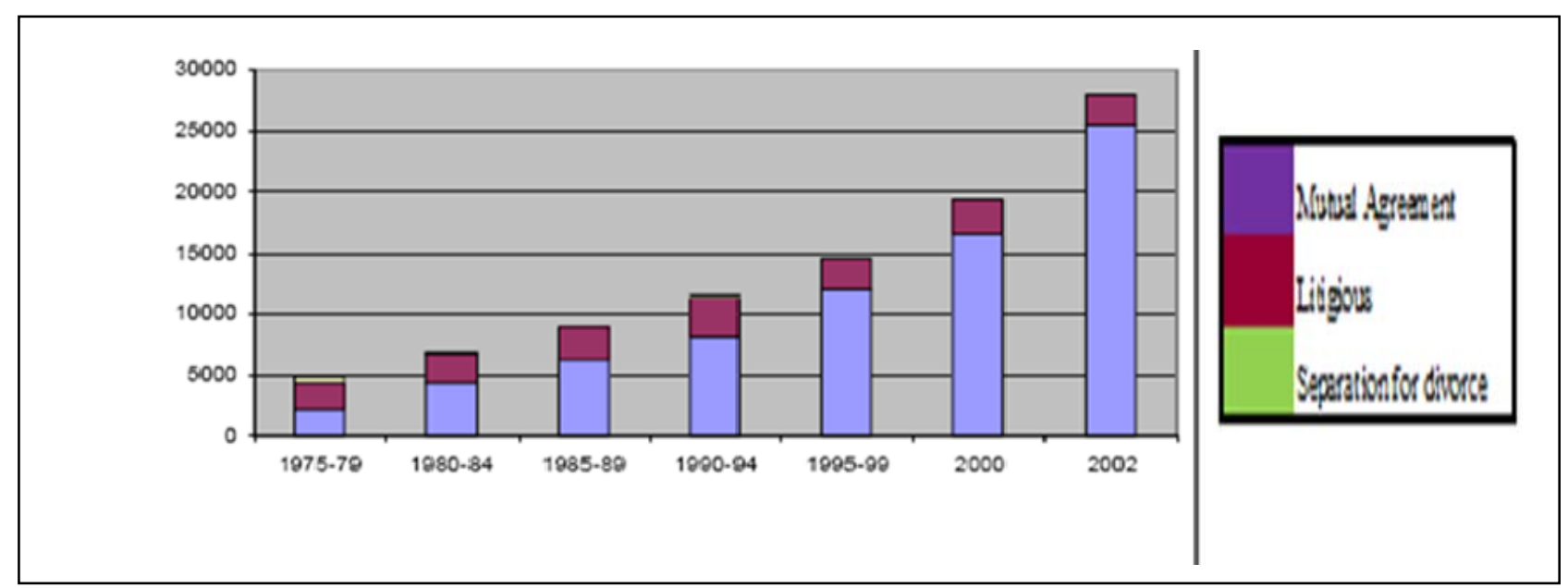

Figure 1. Types of Divorce (1975-2002).

Note: Source: INE, 1975-2002.

In socio-professional terms, even if the tendency for the growth of divorce rate is common to all groups, there is a prevalence of divorce among the employers, liberal professionals, and medium and upper management professions; all of them are supposedly high educated and holders of a comfortable financial autonomy within marriage.

Among the group of divorced people, it is observed that there are more women than men. Demographic factors such as a higher number of women over 25 , as well as socio-cultural factors like the fact that for men there is a wider matrimonial market from the one for women, have led to that. Men not only remarry more often, but also do it with younger, single women, which does not happen with women, who are less inclined for second marriages, be it because they are more autonomous than men on daily tasks, but also because of probably having had negative marital experiences. However, for women, the fact that they hold parenthood power, or it is given to them, in most of the cases, is seen as an obstacle to build a new and durable conjugal relationship or even common law marriage. Finally, in several cases, the permanence of divorced state is a result of the will for a more independent life.

Also in regards to age of divorce, there are some differences between men and women; while proportionally the first shows higher results in higher age groups, the second does it in lower groups. The data point to age differences by the time of the marriage, which can also suggest a women strategy that aims to hedge difficulties or even obstacles to new relationships.

As far as marriage length is concerned, the tendency seen for the last 10 years has witnessed an important growth of divorce among the earliest celebrated marriages (between zero and four years)-12.2\% in 1993, to $19.7 \%$ in 2002 -although longer lasting marriages have been also an increment. In any way, it is the group of married people from five to nine years of marriage length that holds the majority, although it has suffered a relative decrease lately.

With respect to the presence/absence of children within marriage, it does not seem to effectively influence marriage disruption, and it denotes some stability throughout the times. We should emphasize the fact that the occurrence of divorce tends to 
diminish as the number of children grows, which can happen for economical reasons matched with the concern, still pretty much current, that divorce is more harmful than bearing with marriage.

Still on the subject of gender, in litigious cases, women are the ones who most demand for divorce, moreover, the studied cases suggest that there are differences on the motivations/allegations, as well as conduct by both of the parts during the cases, as we will see.

The abolition of the aforementioned figure of blame at the new reform in 2008 reinforces the tendency to increase the divorce rate, as recognized by several other studies [Pompeu Fabra in Spain and Sheffield in United Kingdom (cf. European Economic Review)].

\section{JUDICIAL PROCESS OF DIVORCE: A GENERAL CHARACTERIZATION}

Based on data from sample of 331 divorce processes, it will be able to characterize various aspects of divorce, starting with the distribution of the cases reviewed in 10 counties in Portugal (cf. Figure 2). Most of the observed processes are from counties of the North of Portugal (with 42.3\%), followed by the Central region (38.4\%), and after the South (13.6\%).

Across all the 331 cases observed, it was established the following characterization of marriage rituals. Of the total 331 cases, we found that $66.2 \%$ of marriages were consecrated by the Catholic ritual, 28.7\% through civil marriage (cf. Figure 3). Moreover, collecting data from the INE (Instituto Nacional de Estadística/Institute of National Statistics) in 2008 show (as we could see in Table 1) the types of marriages celebrated in Portugal.

As can be seen, recent data have shown that in 2008, there is a tendency for civil marriages (e.g., 3.100 between 2007 and 2008). If still in 2004, 59.6\% of the Portuguese got married by the church, in 2008 only $44.4 \% \mathrm{did}^{4}$, beyond the rise of unmarried couples.
It appears therefore that, although most of the weddings have been celebrated by the church, this did not prevent the growing demand for divorce. Increasingly, the church and its local representatives - the priests-are losing the ability not only to persuade citizens to marry by the church as to prevent people from divorce, but also to contribute to the recomposition of the productive sectors, the influence of media in changing attitudes and customs.

Another aspect to stress and also not new is the increasing average age at which the Portuguese are married, compared to the past. It is usually that the men undertook later than women; the age difference is now negligible. Men marry, on average, at 32.6 years old and women at 30.1 years old. And while the marriages in the rural context in the past tied up with strategies for preserving heritage, today's later wedding was rather the situations of precariousness and uncertainty at work.

In relation to the system of marriage, observed trials showed the following distribution, as it can be seen in Figure 4. We can verify that, among the cases examined, $66.5 \%$ of marriages were celebrated by the regime of community of acquired property (comunhão de adquiridos), $16 \%$ were concluded by the general communion of goods (comunhão geral de bens), and only $2.7 \%$ by the regime of mandatory separation of property (separação de bens). The set is noted also that in $14.8 \%$, it was unable to determine due to lack of information on processes.

Regarding the duration of marriage, their distribution can be seen in Figure 5. In relation of the length of the marriage, based on processes data, $16.3 \%$ remained in this condition for less than five years, 14.6\% between six and 10 years, 23.8\% between 11 and 15 years, $18.7 \%$ between 16 and 20 years, $18 \%$ between 21 and 30 years, and $8.2 \%$ over 31 years or more. It is important to note that the authors consider 37 cases as not applicable waiver of proceedings or dismissal of the case. In most cases, the duration of marriage focuses on the period between 11 and 31 
Table 1. Marriages in Portugal: Number and Type of Ceremony (2008)

\begin{tabular}{lllll}
\hline \multirow{2}{*}{ Local } & \multicolumn{4}{l}{ Number and form of celebration } \\
\cline { 2 - 5 } & \multicolumn{1}{l}{ Total } & Civil & Catholic & Other \\
\cline { 2 - 5 } & No. & No. & No. & No. \\
\hline Portugal & 43,228 & 23,865 & 19,201 & 162 \\
Continent & 40,730 & 22,106 & 18,466 & 158 \\
Region Açores & 1,345 & 1,032 & 310 & 3 \\
Region Madeira & 1,153 & 727 & 425 & 1 \\
\hline
\end{tabular}

Note: Source: Institute of National Statistics, 2009.

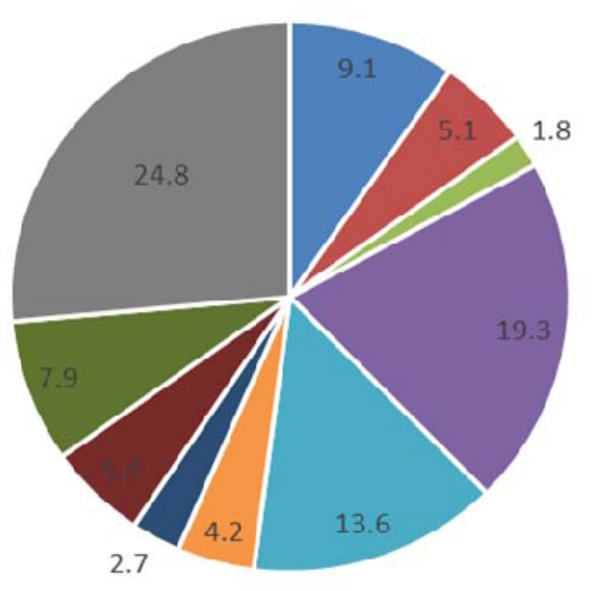

- Braga

- Famalicão

= Guimarães

- Lisboa

- Leiria

= Porto

- Póvoa de Varzim

- Santo Tirso

- Vila do Conde

- Torres Novas

Figure 2. Distribution of Cases by Counties (in \%).

Note: Source: Processos judiciais de divórcio (PJD), 2008-2009 ( $\mathrm{n}=331$ ).

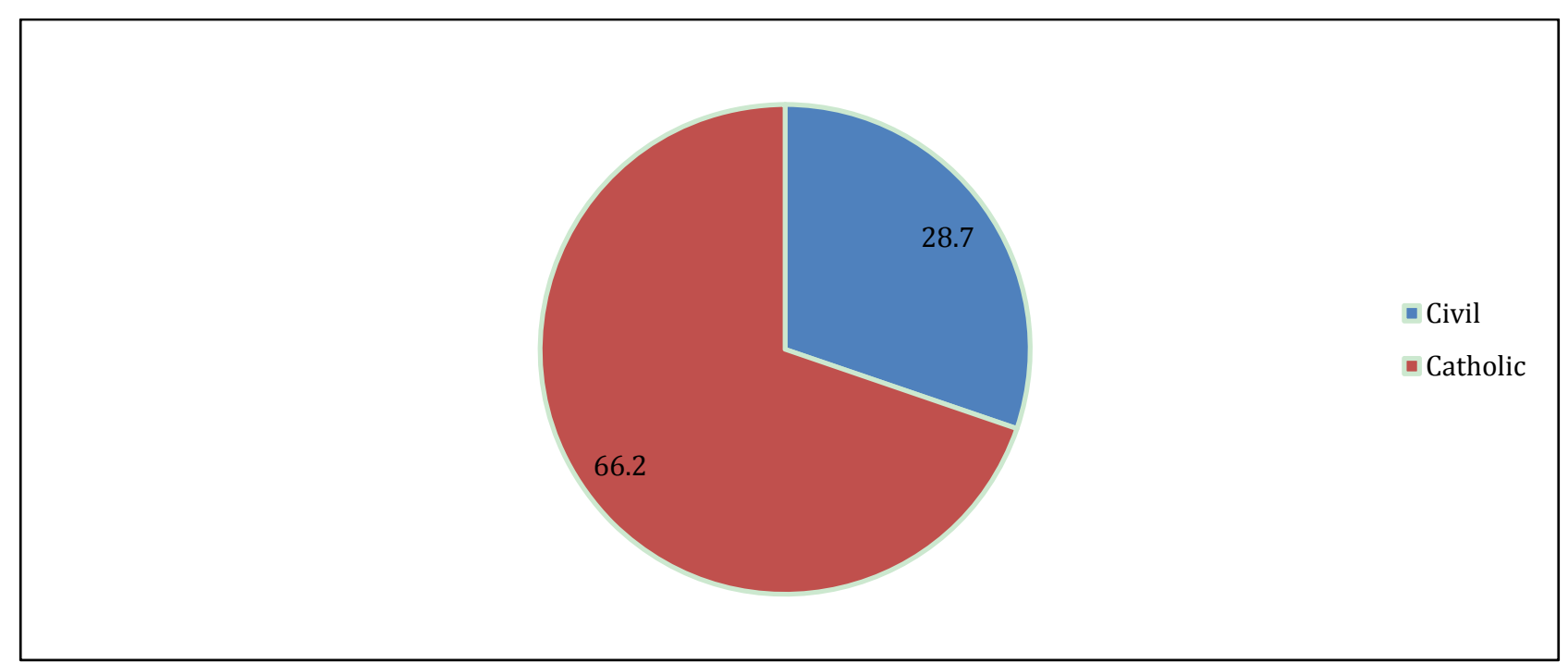

Figure 3. Type of Marriage Ritual of Celebration (in \%).

Notes: Source: PJD, 2008-2009: $\mathrm{n}=314$; unknow/undeterminable: 17. In these, 17 was not possible to know because of the lack of information, namely the inexistence of marriage register attached to the process. 


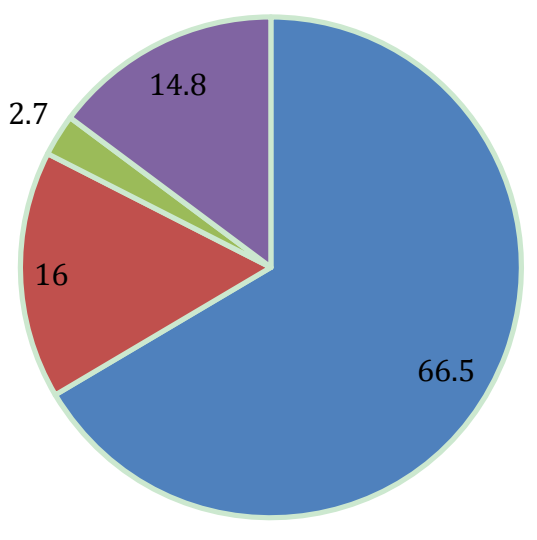

- Community of acquired property

- General communion of goods

- Regime of mandatory separation of property

- Undeterminate

Figure 4. Distribution of Cases by Modalities of Marriage (in \%).

Notes: Source: PJD, 2008-2009: $\mathrm{n}=331$.

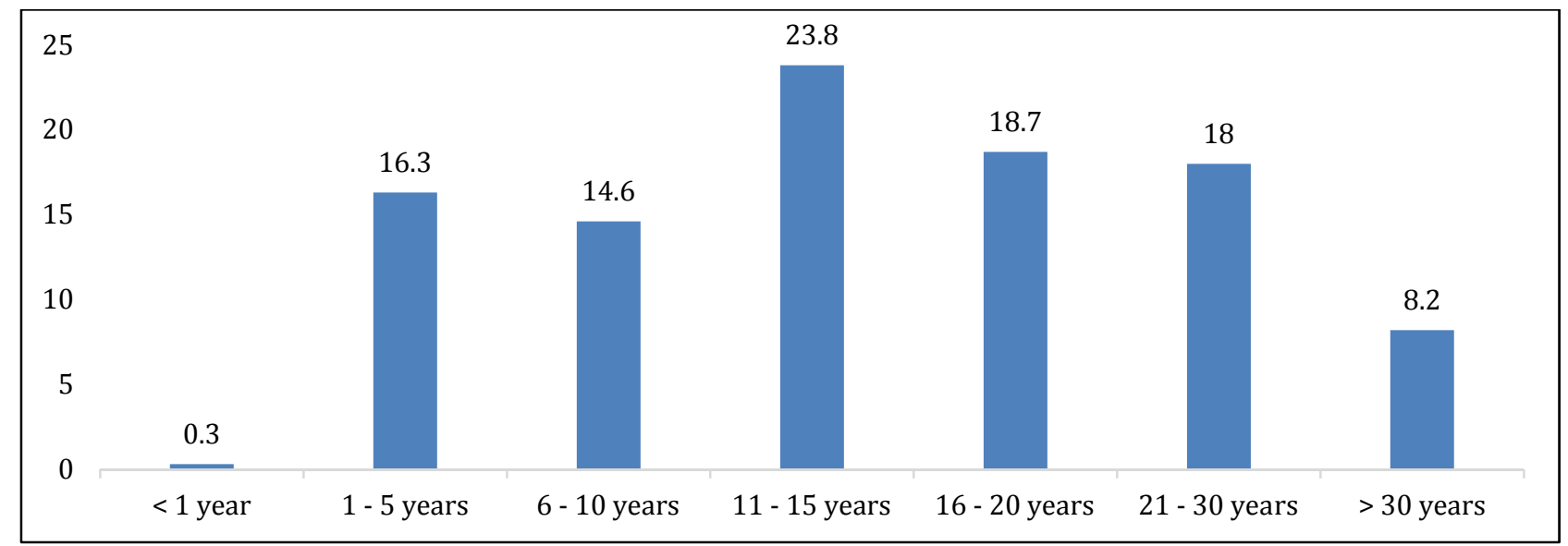

Figure 5. Length of Marriage (Years).

Note: Source: PJD, 2008-2009: $\mathrm{n}=331$.

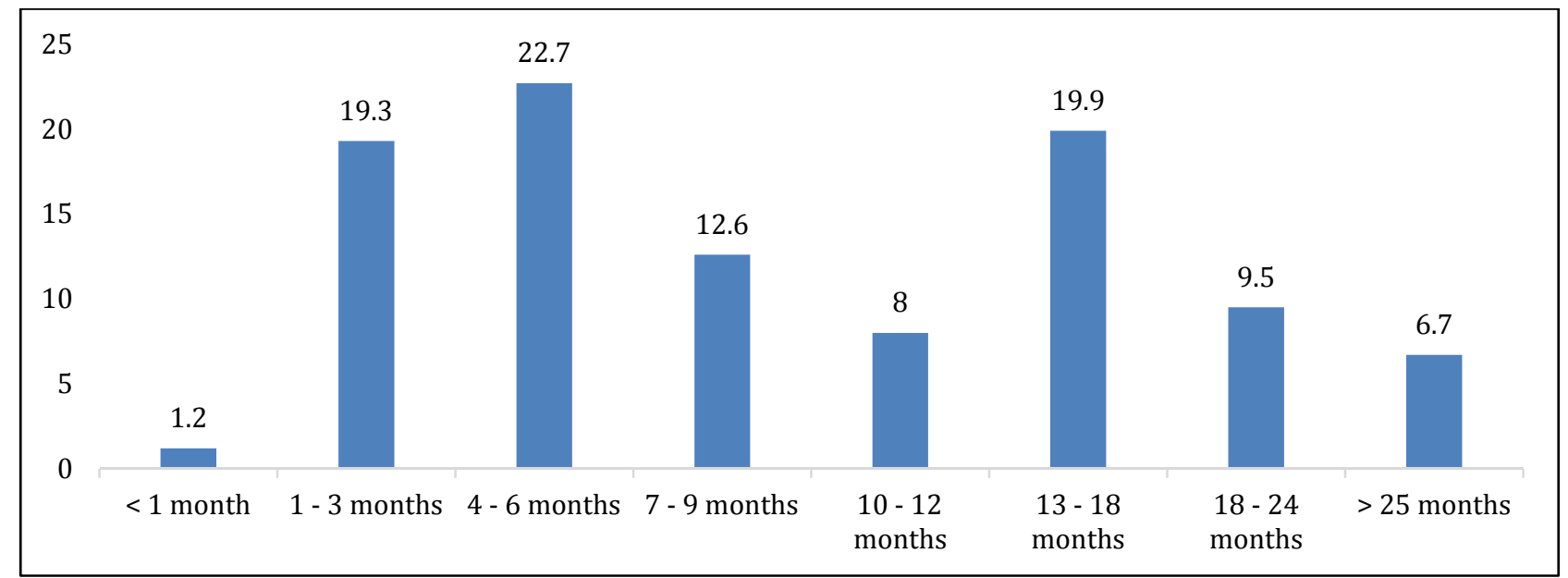

Figure 6. Duration of the Divorce Processes (\%).

Note: Source: PJD, 2008-2009: $\mathrm{n}=326$; not applicable: 5 . 


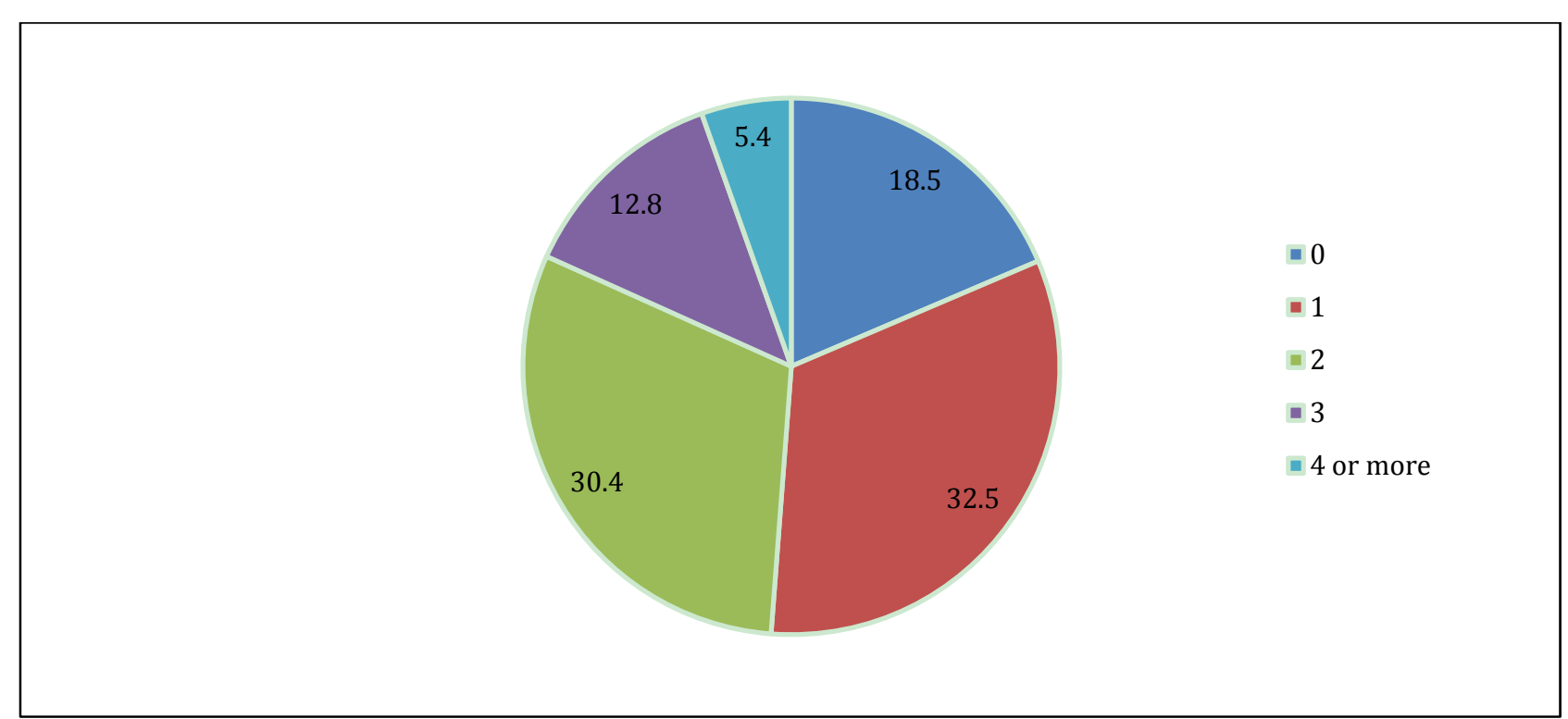

Figure 7. Children of the Marriage (\%).

Note: Source: PJD, 2008-2009, n = 331.

years. Marriages for all life or for long periods are yesterday giving way to less durable marriages, which meets the more general statistical data, reflecting a smaller weight in the effectiveness of social and moral pressure of the church.

For the duration of processes, Figure 6 gives the account of their distribution in terms of time. According to Figure 6, although most people complete the process of divorce in less than a year (63.8\%), there are still $36.1 \%$ where the process drags on beyond a year or more. Considering the cases where there is sharing of goods, while the divorce is decreed in advance, the resolution of these conflicts is still expected to increase the time in dispute.

Finally, it should characterize the households in the divorce process, namely the existence of minor children. Indeed, children are a central element, particularly when there are minor children and it assumes that the law protects under the formula of the supreme interest of the child. Therefore, a first element to know is the number of children per couple, which is given in Figure 7. With the exception of $18.5 \%$ of situations where there are no children of the marriage, in the most cases, there are children, namely one (32.5\%) or two (30.4\%) children, and with lower values three (12.8\%), and four or more children (5.4\%).

In most divorce cases with children, $55.6 \%$ of these are cases with minor children, which allows relativise the idea that these situations are real obstacle to marital dissolution. On the other hand, it also is interesting to note that in the divorce processes are the women that get the minor child custody.

From Table 2, it is evident that $60 \%$ of women with minor children were the plaintiffs of the request for divorce.

\section{DEMAND FOR DIVORCE AND SOCIAL CHARACTERIZATION OF THE PLAINTIFF AND DEFENDANT}

Several studies have verified that most divorces are requested by women, and in this sample, it is also true: $61 \%$ of women-plaintiffs against $39 \%$ of requests by men. Although it cannot be generalized-because the motivations of applications for divorce are different - the 


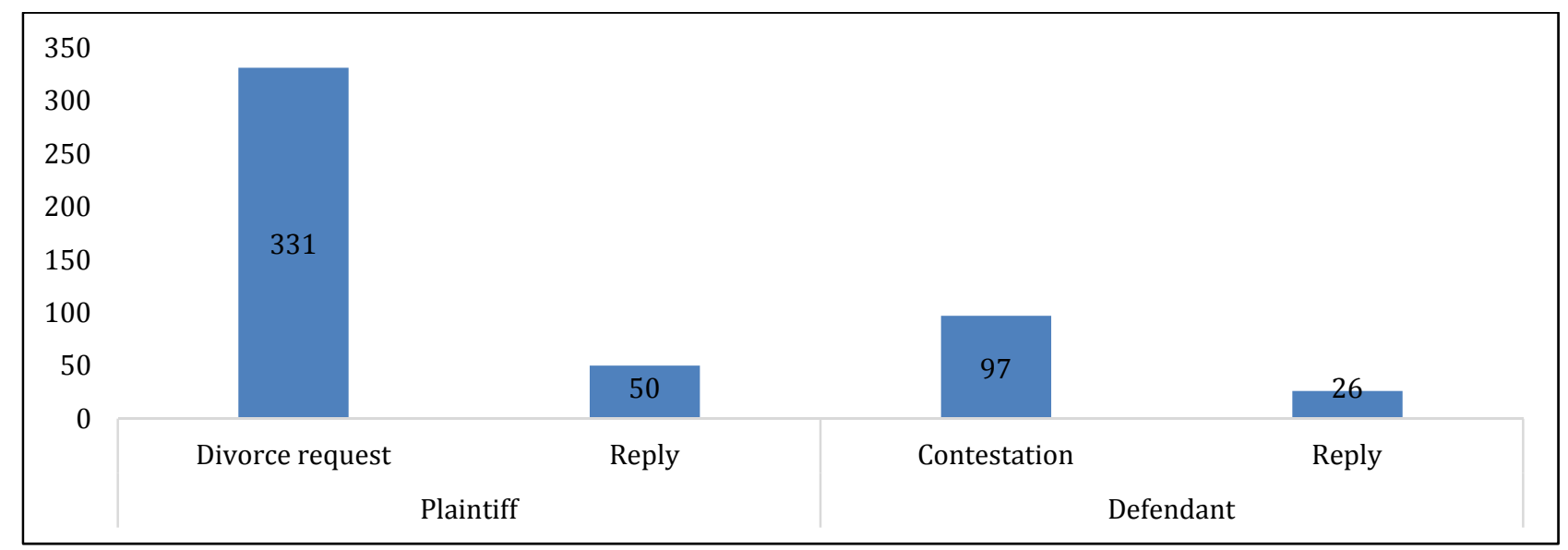

Figure 8. Divorce Request, Contestation, and Replies (No.).

Note: Source: PJD, 2008-2009, $\mathrm{n}=331$.

Table 2. Presence/Absence of Children

\begin{tabular}{|c|c|c|c|c|c|c|}
\hline & & Adult children & Minor children & $\begin{array}{l}\text { Adult and minor } \\
\text { children }\end{array}$ & Without children & Total \\
\hline \multicolumn{7}{|c|}{ Plaintiff } \\
\hline \multirow[t]{2}{*}{ Man } & No. & 23 & 63 & 16 & 27 & 129 \\
\hline & $\%$ & 17 & 49 & 12 & 21 & 100 \\
\hline \multirow[t]{2}{*}{ Woman } & No. & 32 & 121 & 18 & 31 & 202 \\
\hline & $\%$ & 16 & 60 & 9 & 15 & 100 \\
\hline \multirow[t]{2}{*}{ Total } & No. & 55 & 184 & 34 & 58 & 331 \\
\hline & $\%$ & 17 & 56 & 10 & 18 & 100 \\
\hline
\end{tabular}

Note: Source: PJD, 2008-2009, n = 331.

Table 3. Professional Situation of the Plaintiff and of the Defendant

\begin{tabular}{|c|c|c|c|c|}
\hline \multirow{2}{*}{ Professional situation } & \multicolumn{2}{|c|}{ Plaintiff } & \multicolumn{2}{|c|}{ Defendant } \\
\hline & No. & $\%$ & No. & $\%$ \\
\hline Unemployed & 21 & 8.6 & 23 & 11.7 \\
\hline Retired & 21 & 8.6 & 9 & 4.6 \\
\hline Unpaid domestic worker & 41 & 16.7 & 40 & 20.4 \\
\hline Unqualified worker & 60 & 24.5 & 28 & 14.3 \\
\hline Semiqualified worker-employee & 68 & 27.8 & 65 & 33.2 \\
\hline Autonomous family worker & 5 & 2.0 & 1 & .5 \\
\hline As salaried qualified worker & 21 & 8.6 & 12 & 6.1 \\
\hline Autonomous qualified worker & 1 & .4 & 2 & 1.0 \\
\hline Credential petty bourgeoisie & 2 & .8 & 2 & 1.0 \\
\hline Petty bourgeoisie (up to 10 workers) & 4 & 1.6 & 5 & 2.6 \\
\hline Rural owner & & & 7 & 3.6 \\
\hline Middle bourgeoisie (11 to 100 workers) & 1 & .4 & 2 & 1.0 \\
\hline Subtotal & 245 & 100 & 196 & 100 \\
\hline Unknown/not determinable & 86 & $(26.0)$ & 135 & $(40.8)$ \\
\hline Total & 331 & 100 & 331 & 100 \\
\hline
\end{tabular}

Note: Source: PJD, 2008-2009, n = 331. 
Table 4. Remuneration of the Plaintiff and of the Defendant

\begin{tabular}{lllll}
\hline \multirow{2}{*}{ Remuneration } & \multicolumn{3}{c}{ Plaintiff } & \multicolumn{2}{c}{ Defendant } \\
\cline { 2 - 5 } & No. & $\%$ & 35 & 42 \\
\hline$<31 €$ & 87 & 60.5 & 27 & 33 \\
$431-600 €$ & 32 & 22.2 & 12 & 15 \\
$601-1,000 €$ & 12 & 8.3 & 8 & 10 \\
1,001 and $>$ & 13 & 9 & 82 & 100 \\
Subtotal & 144 & 100 & 249 & $(75.2)$ \\
Unknow/undeterminable & 187 & $(56.5)$ & 331 & 100 \\
Total & 331 & 100 &
\end{tabular}

Notes: Source: PJD, 2008-2009, $\mathrm{n}=331$. Previous cases of the eighties did not comprehend information in this regard.

fact that women are to take the initiative of the divorce process is indicative of this feeling, and denotes that women are largely dissatisfied with their marriage.

Looking to know what the profession and/or employment status/class of the plaintiff of the application for divorce, we can verify the results in Table 3. Concerning the professions or occupations of the plaintiffs, given the extreme fragmentation of professions, it was necessary to aggregate them in the categories listed in Table 3, which gives an overview of statutory or class membership as the most adequate in sociological terms. In relation to the unemployed and the retired, without information about past activities, the authors cannot provide any analysis on this subject, and cite the relevant percentages that represent (in both cases: 6.3\%).

Requests for a litigious divorce are somehow cutting across social classes, while less skilled occupations predominate (workers, semi-skilled employees with $24.5 \%$ and $27.8 \%$ respectively and qualified workers with 11\%).

Also among the defendants, the group of (the) semi-skilled employees and unskilled workers will take major shares (respectively $14.3 \%$ and $33.2 \%$ ) and of domestic unpaid with $20.4 \%$ and unemployed with $11.7 \%$. In the remaining groups, the percentages have been somewhat residual.

The plaintiffs and the defendants had lower wages, as we can see from Table 4. As can be seen, without accounting for $56.5 \%$ of the plaintiffs without knowledge in this area and $75.2 \%$ of defendants without information in this area, $60.5 \%$ of the plaintiffs and $42 \%$ of the accused/defendants have incomes at or below 430 euros, which indicates that people who most seek divorce have low incomes or are beneficiaries of minimum income. Following are $22.2 \%$ of plaintiffs and $33 \%$ of defendants between 431 and 600 euros and $8.3 \%$ of plaintiffs and 15\% of defendants between 601 and 1,000 euros and above 1,000 euros are a minority ( $9 \%$ and $10 \%$ respectively). Moreover, given the lack of information, it was not possible to know the qualifications of the plaintiffs and the defendants.

Everything indicates that for a considerable part of the plaintiffs and especially the women-plaintiffs who requested the divorce, this demand is a fact and means a symptom of increased difficulties in their lives, which is incidentally also confirmed by the need to seek legal aid in the process of the judicial divorce by 185 (55.9\%) cases, of which 168 (90\%) were considered and, to a lesser extent, by 75 defendants, 64 of which were accepted (85\%).

\section{PROCESSES AND JUDGES SENTENCES: A GENDER PERSPECTIVE}

If the authors want to analyze the arguments and motivations used by the gender perspective, either 
upon petition of the plaintiff, or when the dispute by the defendant, Tables 5 and 6 give an account of the perspectives that either are convergent or divergent. Consider, first, the arguments and motivations at the request of plaintiff by sex (cf. Appendix 1). As we can see, the arguments and motivations for divorce by women as plaintiffs, between $60 \%$ and $93 \%$ of cases, differ considerably from that of men as plaintiffs with higher percentages concerning the deterioration of marriage life, separation of bodies, no contribution to household expenses, defendant husband guilty of discussions, lack of affection and attention with the children, verbal and physical violence aggressions, abuses and injuries, illness without the support of the defendant, addiction, unemployment, alcoholism, infidelity, the defendant's membership outside marriage, absence or leaving home, besides de facto separation.

As male plaintiff, the arguments and motivations put forward, except $80 \%$ pointing to guilt of the defendant-woman in a bad relationship with their children (80\%), have much lower percentages (between 30\% and 50\%), highlighting the forced exit from the household, the extra-marital relationships of the defendant or vague arguments as incompatibilities of character or divergence in the form of children's education or simply formal reasons of law such as de facto separation for three consecutive years, the purpose of not reinstating for living together.

Also in dispute is the case of similar allegations by the man as defendant, as shown in Appendix 2. In order to assess the nature and extent of litigation, the authors try to know the extent to which the defendant was the defense and reverse, a reply of the plaintiff/rejoinder by the accused/defendant, which can be seen in Figure 8. Indeed, of the 331 applications for divorce required by the plaintiffs, 97 were contested. However, these contestations were held by the reply of 50 plaintiffs, completing the opening arguments in the application for divorce or replying to the defense of the defendants. In turn, to the replies of the plaintiffs, it was found that the defendants' rejoinder/reply was 26.

Seeking to know the sex of the judge busy with their own processes, of the total judges who conducted the trial of 331 cases of divorce, except that 2.1\% could not be determined for lack of information, $68 \%$ are male and $29.2 \%$ are female.

A usual part in court proceedings is the evidence, including the witnesses; it is useful to account for the sex and number of witnesses presented by either plaintiff or by the defendant, as shown in Figure 9.

Given the figure, we can see that there is a substantially larger volume of witnesses presented by the female plaintiffs (652 to 358) compared to the male plaintiffs, which can be explained largely by greater numbers of women to advance the demand for divorce and the greater number of witnesses submitted/presented by women. In the case of the defendants, there is an approximation of values, though, here too, the women present a larger number of witnesses, allowing somehow qualify the earlier advanced/provided explanation.

Regarding the sex of the witnesses, as we can see from Figure 10, it is noteworthy that both for the plaintiffs and for the defendants, while men tend to have a majority of witnesses, with women it is the opposite, presenting them also women witnesses. This happens with very similar percentages in both cases, as we can see.

Finally, it is important to analyze the sex of representatives chosen by men and women, either as plaintiffs, or as defendants. Of the 331 divorce cases examined, there are witnesses presented by both the plaintiff as the culprit/defendant; but while by the plaintiffs are presented 235 witnesses, among the defendants only 78 did it. It is important to interpret these data given that, firstly, be a small percentage of disputes and, secondly, the fact that not all cases end with a court order, and in the event that turned into mutual consent earlier the trial, witnesses are not presented. The same is true in some cases in which 
Table 5. Plaintiff of the Case and Representative by Sex

\begin{tabular}{lllllll}
\hline \multirow{2}{*}{ Plaintiff sex } & \multicolumn{5}{c}{ Representative } & \multicolumn{3}{c}{ Total } \\
\cline { 2 - 7 } & \multicolumn{5}{c}{ Man } & \multicolumn{3}{c}{ Woman } & No. & $\%$ \\
\hline Man & No. & $\%$ & No. & $\%$ & 119 & 38.3 \\
Woman & 89 & 74.8 & 30 & 25.2 & 192 & 61.7 \\
Total & 126 & 65.6 & 66 & 34.4 & 311 & 100 \\
\hline
\end{tabular}

Note: Source: PJD, 2008-2009, $\mathrm{n}=311$; undeterminable: 20 cases (6\%).

Table 6. Defendant of the Case and Representative by Sex

\begin{tabular}{lllllll}
\hline \multirow{2}{*}{ Defendant Sex } & \multicolumn{5}{c}{ Representative } & Total \\
\cline { 2 - 7 } & No. & $\%$ & No. & $\%$ & No. & $\%$ \\
\hline Man & 63 & 73.3 & 62 & 73.8 & 125 & 73.5 \\
Woman & 23 & 26.7 & 22 & 26.2 & 45 & 26.5 \\
Total & 86 & 100 & 84 & 100 & 170 & 100 \\
\hline
\end{tabular}

Note: Source: PJD, 2008-2009, $\mathrm{n}=170$; undeterminable: 161 cases $(48.6 \%)$.

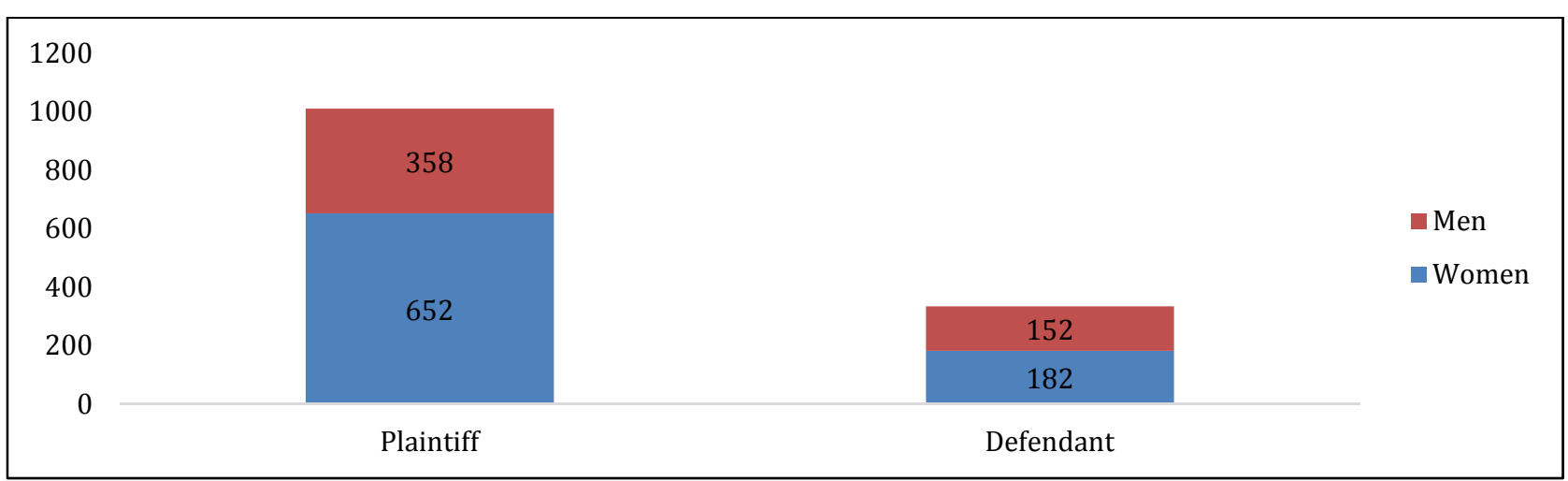

Figure 9. Number of Witnesses Presented by the Plaintiff/Defendant by Sex.

Note: Source: PJD, 2008-2009.

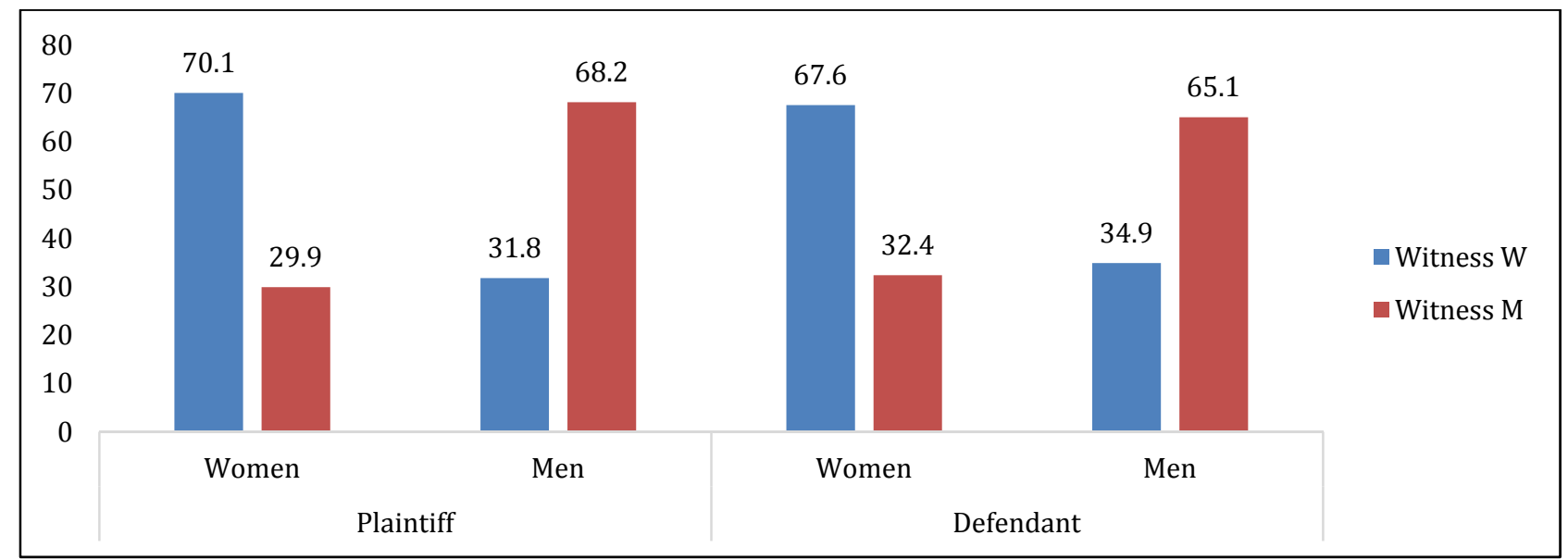

Figure 10. Sex of the Witnesses Presented by the Plaintiff and by the Defendant (\%).

Note: Source: PJD, 2008-2009. 
Table 7. Finalization of the Process by Plaintiff's Sex

\begin{tabular}{|c|c|c|c|c|}
\hline & & \multicolumn{2}{|c|}{ Plaintiff's sex } & \multirow{2}{*}{-Total } \\
\hline & & Man & Woman & \\
\hline \multirow{2}{*}{ Discontinuance } & No. & 4 & 8 & 12 \\
\hline & $\%$ & .3 & .7 & 1.0 \\
\hline \multirow{2}{*}{ Court decision } & No. & 66 & 101 & 167 \\
\hline & $\%$ & 40 & 60 & 100 \\
\hline \multirow{2}{*}{ Mutual agreement during the trial } & No. & 31 & 40 & 71 \\
\hline & $\%$ & 44 & 56 & 100 \\
\hline \multirow{2}{*}{ Mutual agreement before the trial } & No. & 22 & 44 & 66 \\
\hline & $\%$ & 33 & 67 & 100 \\
\hline \multirow{2}{*}{ Reconciliation before the trial } & No. & 4 & 4 & 8 \\
\hline & $\%$ & 50 & 50 & 100 \\
\hline \multirow{2}{*}{ Reconciliation during the trial } & No. & 2 & 5 & 6 \\
\hline & $\%$ & 18 & 83 & 100 \\
\hline \multirow{2}{*}{ Total } & No. & 129 & 202 & 331 \\
\hline & $\%$ & 39 & 61 & 100 \\
\hline
\end{tabular}

Note: Source: PJD, 2008-2009, $\mathrm{n}=170$; undeterminable: 161 cases (48.6\%).

Table 8. Finalization of the Process by Judge Sex

\begin{tabular}{llll}
\hline & \multicolumn{3}{c}{ Judge sex } \\
\cline { 2 - 4 } & Man & Women & $8100 \%$ \\
\hline Discontinuance & $675 \%$ & $225 \%$ & $166100 \%$ \\
Court decision & $14084 \%$ & $2616 \%$ & $71100 \%$ \\
Mutual agreement during the trial & $3955 \%$ & $3245 \%$ & $66100 \%$ \\
Mutual agreement before the trial & $3045 \%$ & $3655 \%$ & $7100 \%$ \\
Reconciliation before the trial & $683 \%$ & $117 \%$ & $6100 \%$ \\
Reconciliation during the trial & $467 \%$ & $233 \%$ & $324100 \%$ \\
Total & $22569 \%$ & $9931 \%$ & \\
\hline
\end{tabular}

Note: Source: Arquivo Distrital de Lisboa (Districtal Archive of Lisbon); n = 324; undeterminable: 7.

action was unfounded or the process is withdrawn. If we want to know how many witnesses were mobilized by the plaintiffs and by the defendants and their distribution by sex, Table 7 gives the degree of involvement of third parties.

Table 5 shows that not only male and female plaintiffs are looking for more male lawyers than female lawyers who advocated, which is not surprising given the recent feminization processes of lawyers. A different pattern may occur in relation to lawyers of the defendants, where there is a greater balance, being, however, the sample also lower.

Indeed, there is a greater demand for male lawyers, even by women. This finding, in addition to greater numbers of men to engage in advocacy, can also be a symptom of the reinforcement of traditional gender stereotypes, also shared by women.

Regarding the finalization of the process by gender of the plaintiff, Table 7 gives the following results:

It should be noted that in most cases (167), it takes place through the courts, following the cases of conversion into common consent during the trial (71), conversion into a mutual agreement before the trial (66), being residual the remaining cases (withdrawal, rejection, and reconciliation). If we want to measure 
the finalizations of process by sex of judge, Table 8 presents highlights that in most cases (166) it takes place through the courts, following the cases of conversion into mutual agreement during the trial (71), conversion into a mutual agreement before the trial (66), being residual the remaining cases (withdrawal, rejection, and reconciliation).

\section{CONCLUSIONS}

This paper, being a piecemeal result of a project about gender inequalities in work and private life wanted to make a contribution to the knowledge of the reality of gender inequalities in Portugal. It was given a brief theoretical framework plus an important historical overview of gender inequalities especially on divorce particularly since the New State (Estado Novo).

In a second step, the authors focus on the question of parity either within marriage, or in the context of divorce, considering the parity law on several fronts: in family, employment, and political life, which allowed to get an idea of progress done and what remains to be done to achieve real gender parity. Recently the authors confront with a new divorce law where this concept is disproved by the guilty element.

Finally, in a third time, the authors analyzed 331 court cases collected in 10 counties in Northern, Central, and Southern Portugal. These data suggest that, beyond the particularities of that line the divorce court, there are considerable differences depending on that the plaintiff is the man or woman. The cases where the request is made by women appear in most cases as a result of extreme situations, such as subjecting the continuing violence and lack of effective input from man to support her family, which, for men, it is very limited and minor.

For men, the requests appear to the current pattern towards the settlement of situations of separation and it is not surprising about these cases of separation, most of them being converted into divorce by mutual consent. Moreover, the responsibilities of women in the family, regarding the implementation of the various household chores are stereotypically assumed by men as exclusive of the women. When these tasks are given as fickle or not met by the woman, although this is not recorded or valued in written decisions, such facts are adduced by men in their pleadings.

Finally, in processes, arguments, and their own judgments of the judges, there are still some gender stereotypes, including the proper attribution of parental responsibility over their children. These stereotypes continue to be crucial in the construction of inequalities between women and men, affecting all spheres of social, political, economic, and cultural conditioning of the values, language, expectations, behaviors, and choices. It is urgent thereby to develop a concerted effort to combat gender stereotypes in all areas and in particular in education and training, health, labor market, sport and culture, media, and in all areas of political and public life, that are structuring of an active and responsible citizenship. 


\section{APPENDIX}

Appendix 1. Plaintiffs' Demand for Divorce: Arguments and Motivations by Sex

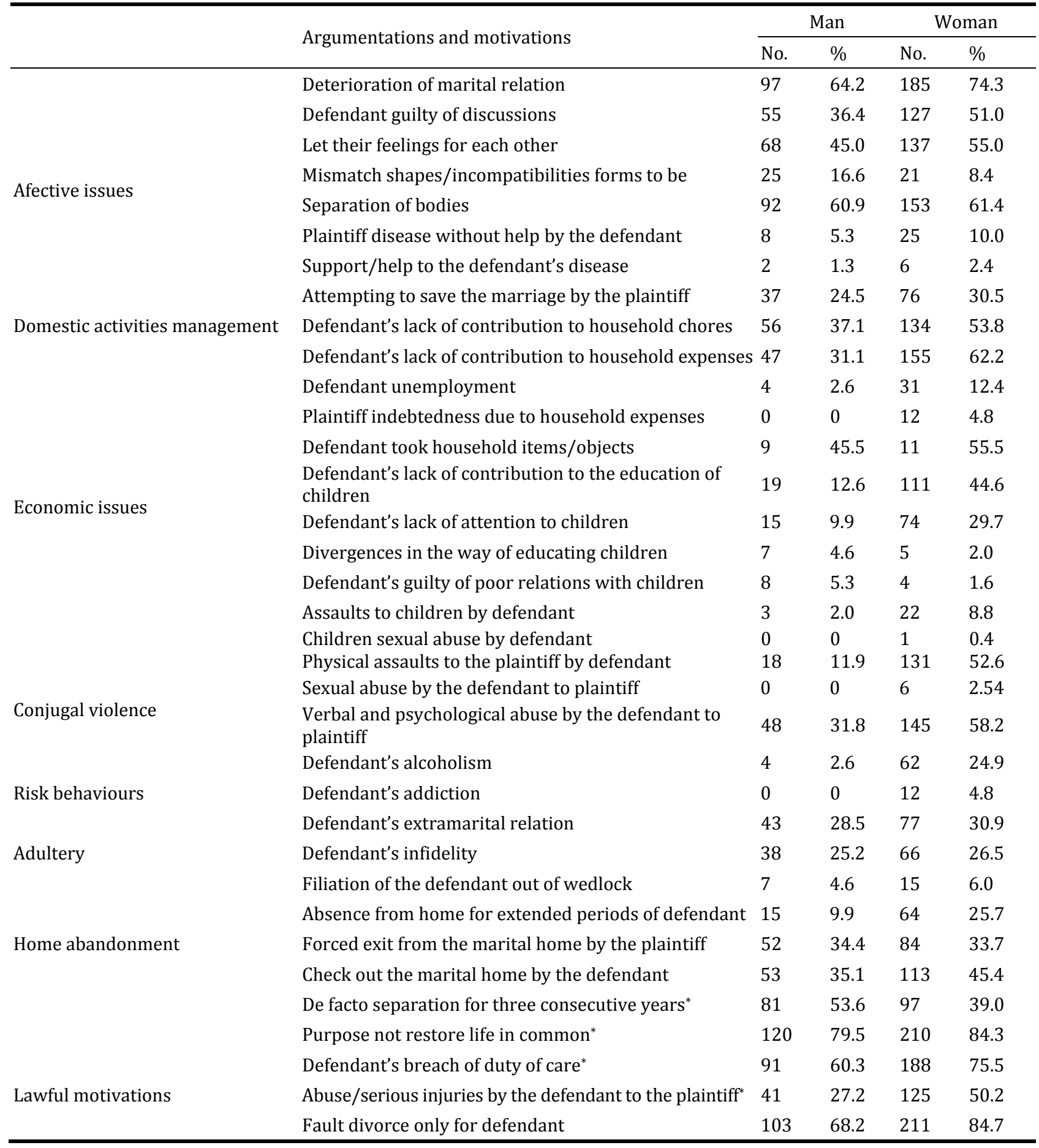

Note: Source: PJD, 2008-2009, $\mathrm{n}=331$; $^{*}$ for juridical law. 
Appendix 2. Challenge of the Defendant to the Plaintiff: Arguments and Reasons by Sex

\begin{tabular}{|c|c|c|c|c|c|}
\hline & \multirow{2}{*}{ Argumentations and motivations } & \multicolumn{2}{|c|}{ Man } & \multicolumn{2}{|c|}{ Woman } \\
\hline & & No. & $\%$ & No. & $\%$ \\
\hline \multirow{8}{*}{ Afective issues } & Deterioration of marital relation & 97 & 64.2 & 185 & 74.3 \\
\hline & Defendant guilty of discussions & 55 & 36.4 & 127 & 51 \\
\hline & Let their feelings for each other & 68 & 45 & 137 & 55 \\
\hline & Mismatch shapes/incompatibilities forms to be & 25 & 16.6 & 21 & 8.4 \\
\hline & Separation of bodies & 92 & 60.9 & 153 & 61.4 \\
\hline & Plaintiff disease without help by the defendant & 8 & 5.3 & 25 & 10 \\
\hline & Support/help to the defendant's disease & 2 & 1.3 & 6 & 2.4 \\
\hline & Attempting to save the marriage by the plaintiff & 37 & 24.5 & 76 & 30.5 \\
\hline \multirow[t]{2}{*}{ House chores management } & Defendant's lack of contribution to household chores & 56 & 37.1 & 134 & 53.8 \\
\hline & Defendant's lack of contribution to household expenses & 47 & 31.1 & 155 & 62.2 \\
\hline \multirow{3}{*}{ Economic issues } & Defendant unemployment & 4 & 2.6 & 31 & 12.4 \\
\hline & Plaintiff indebtedness due to household expenses & 0 & 0 & 12 & 4.8 \\
\hline & Defendant took household items/objects & 9 & 45.5 & 11 & 55.5 \\
\hline \multirow{6}{*}{$\begin{array}{l}\text { Caring, education and } \\
\text { relationship with the } \\
\text { children }\end{array}$} & Defendant's lack of contribution to the education of children & 19 & 12.6 & 111 & 44.6 \\
\hline & Defendant's lack of attention to children & 15 & 9.9 & 74 & 29.7 \\
\hline & Divergences in the way of educating children & 7 & 4.6 & 5 & 2 \\
\hline & Defendant's guilty of poor relations with children & 8 & 5.3 & 4 & 1.6 \\
\hline & Assaults to children by defendant & 3 & 2 & 22 & 8.8 \\
\hline & Children sexual abuse by defendant & 0 & 0 & 1 & 0.4 \\
\hline \multirow{3}{*}{ Conjugal violence } & Physical assaults to the plaintiff by defendant & 18 & 11.9 & 131 & 52.6 \\
\hline & Sexual abuse by the defendant to plaintiff & 0 & 0 & 6 & 2.54 \\
\hline & Verbal and psychological abuse by the defendant to plaintiff & 48 & 31.8 & 145 & 58.2 \\
\hline \multirow{2}{*}{ Risk behaviour } & Defendant's alcoholism & 4 & 2.6 & 62 & 24.9 \\
\hline & Defendant's addiction & 0 & 0 & 12 & 4.8 \\
\hline \multirow{3}{*}{ Adultery } & Defendant's extramarital relation & 43 & 28.5 & 77 & 30.9 \\
\hline & Defendant's infidelity & 38 & 25.2 & 66 & 26.5 \\
\hline & Filiation of the defendant out of wedlock & 7 & 4.6 & 15 & 6 \\
\hline \multirow{3}{*}{ Home abandonment } & Absence from home for extended periods of defendant & 15 & 9.9 & 64 & 25.7 \\
\hline & Forced exit from the marital home by the plaintiff & 52 & 34.4 & 84 & 33.7 \\
\hline & Check out the marital home by the defendant & 53 & 35.1 & 113 & 45.4 \\
\hline \multirow{5}{*}{ Lawful motivations } & De facto separation for three consecutive years* & 81 & 53.6 & 97 & 39 \\
\hline & Purpose not restore life in common* & 120 & 79.5 & 210 & 84.3 \\
\hline & Defendant's breach of duty of care* & 91 & 60.3 & 188 & 75.5 \\
\hline & Abuse/serious injuries by the defendant to the plaintiff* & 41 & 27.2 & 125 & 50.2 \\
\hline & Fault divorce only for defendant & 103 & 68.2 & 211 & 84.7 \\
\hline
\end{tabular}

Note: Source: PJD, 2008-2009, n = 97. 


\section{Notes}

1. This paper is a partial result of the investigation process "(In)nequalities in work and private life: from laws to social practice” (finish in 2012), which is under responsibility of Manuel Carlos Silva and realized in the Research Centre CICS.Nova_UMinho (Interdisciplinar Centre of Social Sciences).

2. Provisional data provided by INE.

3. The evolution of this should be followed because in Portugal between the decade of 90 and 2005 there was a great increment of religious practice that put us in a top of the list position even when compared to countries like Spain and Italy (cf. EVV 2005).

4. It is, however, in the North that the Portuguese still prefer the religious ritual. In 2008, 54.7\% still did (against 57.9\% in 2007). In the Centre, the couples split up: $50 \%$ chose the Catholic rite. The Azores and the Algarve are the regions where the religious wedding has less weight (23.4\% and 23\% respectively). Also according to Mário Bandeira, this "will certainly have to do with a cultural issue. The Southern people have always been more secularist and less traditionalist. Certainly there are many couples living together, but who do not celebrate the union in fact does not contribute to statistics” (2009).

\section{References}

Abbott, P. and C. Wallace. 1991. Gender, Power and Sexuality. Basingstoke: Macmilan.

Bourdieu, P. 1980. Le sens pratique (The Logic of Practice). Paris: Minuit.

—. 1999. A dominação masculina (Masculine Domination). Oeiras: Celta.

Crompton, R. 2003. "Class and Gender Beyond the 'Cultural Turn'.” Sociologia, Problemas e Práticas 42:9-24.

Engels, F. 1964 (1884). A origem da família, da propriedade privada e do Estado (The Origin of the Family, Private Property and the State). Rio de Janeiro: Editorial Vitória.

Ferreira, V. 1993. "Padrões de segregação das mulheres no emprego-uma análise do caso português no quadro europeu" (Segregation Patterns of Women in Employment-An Analysis of the Portuguese Case in the European Framework). Pp. 231-257 in Portugal: um retrato singular (Portugal: A Singular Portrait), edited by B. S. Santos. Porto: Afrontamento.

Foucault, M. 1979. A microfísica do poder (The Microphysics of Power). Rio de Janeiro: Graal.

Goffman, E. 1974. Les rites d' interaction (Interaction Ritual).
Paris: Minuit.

Machado, H. 2005. "Transaç̧ões discursivas em contexto judicial—construções femininas e masculinas” (Discursive Transactions in Legal Context-Female and Male Constructions). Configurações 1:133-147.

Parsons, T. 1956. "Family Structure and the Socialization of the Child.” Pp. 35-131 in Family, Socialization and Interaction Process, edited by T. Parsons and R. Bales. London: Routledge.

Ritzer, G. 1996. Modern Sociological Theory. 4th ed. New York: McGraw Hill Companies, Inc.

Roberts, R. 1984. “Women’s Work and Women's Property: Household Social Relationship in the Maraka Textil Industry of Nineteenth Century." Comparative Studies in Society and History 26(2):229-240.

Scott, J. 1990. Domination and the Arts of Resistence-Hidden Transcripts. New Haven/London: Yale University Press.

Segalen, M. 1983 (1980). Love and Power in the Peasant Family. Rural France in the Nineteenth Century. Chicago: The University of Chicago Press.

Silva, M. C. 1993. "Casa e casas em espaço rural minhoto" (House and Homes in Rural Areas of Minho). Actas do II Congresso Português de Sociologia I:922-939.

- 1998. Resistir e adaptar-se. Constrangimentos e estratégias camponesas no noroeste de Portugal (Resistance and Adaptation. Constraints and Peasant Strategies in Northwest of Portugal). Porto: Afrontamento.

—. 2003. "Honra e vergonha: código cultural mediterrânico ou forma de controlo de mulheres" (Honor and Shame: Mediterranean Cultural Code or Way to Control Women)? Pp. 67-86 in Portugal-Chão (Portugal-Ground), edited by J. Portela and J. C. Caldas. Oeiras: Celta.

- 2005. "Trabalhadoras sexuais em regiões de fronteira: género, origens de classe e percursos sociais” (Sex Workers in Border Regions: Gender, Class Origins and Social Pathways). Configurações 1(1):101-133.

Sottomayor, M. C. 2002. Regulação do Exercício do Poder Paternal nos Casos de Divórcio (The Exercise of Parental Authority in Cases of Divorce). Coimbra: Livraria Almedina.

Torres, A. C. 1996. O Divórcio em Portugal, Ditos e Interditos: Uma Análise Sociológica (Divorce in Portugal. Sayings and Prohibited: A Sociological Analysis). Oeiras: Celta Editora.

- 2001. Sociologia do Casamento. A Família e a Questão Feminina (Sociology of Marriage. The Family and the Feminist Issue). Oeiras: Celta.

Viegas, J. M. L. and S. Faria. 1999. As mulheres na política (Women in Politics). Lisboa: Imprensa Nacional Casa da Moeda.

Walby, S. 1997. Gender Transformations. London: Routledge. 
Wall, K., ed. 2005. Famílias em Portugal (Families in Portugal). Lisboa: ICS, Imprensa de Ciências Sociais.

Weber, M. 1978 (1920). Economy and Society. Berkeley: University of California Press.

\section{Bios}

Manuel Carlos Silva, Ph.D., visitant professor in
Postgraduation Development, Society and Cooperation/Centre of Advanced Multidisciplinar Studies/CEAM, National University of Brasilia and researcher in Interdisciplinar Centre of Social Sciences (CICS.Nova_UMinho), University of Minho, Portugal; research fields: rural-urban sociology, development sociology, class, gender and ethnical inequalities.

Ana Reis Jorge, PhD student in Sociology, Interdisciplinar Centre of Social Sciences (CICS.Nova_UMinho), University of Minho, Portugal; research field: gender inequalities. 